\title{
Specific approach to select of freight elevators for multi-floor manufacturing
}

\author{
JEL: L91 DOI: 10.24136/atest.2018.550 \\ Data zgłoszenia: 19.11.2018Ｄata akceptacji: 15.12.2018
}

The application of multi-floor cellular manufacturing in huge cities is related to the rational use of urban areas and the solution of traffic problems. The select of freight elevators is a vital part of decision process in the multi-floor manufacturing which allows the enterprise to select equipment considering technical, economic, environmental, social and other factors. This paper presents the specific approach to the selection of freight elevators for the multi-floor cellular manufacturing. A model for freight elevators selection is proposed considering the manufacturing performance, the carrying capacity of vertical transport system, and the number of floors of cellular manufacturing.

Keywords: multi-floor manufacturing, freight elevator, performance.

\section{Introduction}

The extreme environmental and traffic problems in huge cities are caused by a global structural change in modern urbanization, one of the manifestations of which is an increase in several high-rise buildings, including multi-floor manufacturing, in the total volume of construction. This trend is continued with the structural changes in all sectors of the industry due to the emergence of new technologies and processes, improving transportation communications, creation of innovative products and services, qualitative change of the labor resources, modern methods of management, and more efficient use of natural resources. The multi-floor factories in the huge cities are associated as good neighbors in a modern urban environment $[1,2$, and 3].

The main factor hampering the widespread use of the multi-floor factories in the urban environment is the use of bulky and largescale technological equipment with a high level of power consumption and of the assembly laboriousness mainly in the conditions of factory-manufacturer. The solution of the problem is related to creation of the facilitated and easily collected technological equipment of modular design, for example, of frame constructions [4], with the manufacturer to the customer delivery being carried out only in the disassembled state. The decline of the performance of the facilitated manufacturing equipment is compensated by mass character of its application, and the rational use of the urban areas and transport communications which provide efficiency of the multi-floor productions in the huge cities [5].

Effective operation of the multi-floor manufacturing depends on the optimal select of freight elevators based on the harmonization of their throughput with the production performance. The modern market offers a wide range of freight elevators with different technical characteristics, which determines the need to establish criteria for their selection for the multi-floor manufacturing. The decision support in the selection of the freight elevators is based on multicriteria that consider project outcomes along three dimensions technical, socio-ecological and financial-economic [6, 7, 8, and 9]. However, in the planning of the multi-floor manufacturing, one of the main criteria for selecting the freight elevators is to ensure the high- est performance, considering the types of production process organization, the number of floors of the building, the interfloor distance and their technical characteristics [10].

In the multi-floor manufacturing all known types of production process organization can be used: linear, cellular and technological forms, layout for immobile items, mixed forms [11]. Type of the production process organization determines the freight elevators traffic, which is fundamental to the planning and design of elevator systems [7, 10, and 12]. This paper considers the problems of the freight elevators selection for the multi-floor manufacturing with a cellular form of the production process organization. In the multifloor cellular manufacturing all finished products and workpieces come from each floor to the main storage, located on the ground floor, and then are shipped to the outside consumer or are delivered by the freight elevators to another floor of the building to perform subsequent technology operations.

For the multi-floor cellular manufacturing the equations for anaIytical calculations of the freight elevators round trip time [5] and the optimal number of the freight elevators are obtained, based on an assessment of their throughput and production performance [10]. An important aspect of the planning and design of the multi-floor cellular manufacturing is the assessment of freight elevators, based on the analysis and comparison of their capacity for making decisions on introduction of an effective elevator system. A specific approach to assessment and select of the efficient elevator systems is to ensure the highest performance of the multi-floor cellular manufacturing.

The purpose of this paper is to describe a specific approach to the selection of freight elevators for multi-floor cellular manufacturing.

\section{The select of freight elevators for the multi-floor cellular manufacturing by the performance criteria}

Each freight elevators occupies the $S_{E}$ area, respectively, which is part of the total $S$ area of cellular manufacturing on each floor. The layout of the technological equipment of the enterprises in the multi-floor manufacturing depends on many factors, among them basic ones are the type, weight and dimensions of the products, and the applied technological process. As an example, on Fig. 1 the charts of the technological equipment and the freight elevators layout are presented in the multi-floor cellular manufacturing. The multi-floor cellular manufacturing includes the technological equipment 1 , freight elevators 2 , and trolleys 3 . Delivery of the components, tools and consumables for the technological equipment, loading and unloading of products and wastes from are carried out by freight elevators and trolleys. Trolleys filled with products or wastes are shipped on the main storage (ground floor). The specific approach to assessment and select of technologies for the multifloor manufacturing is related with weight distributions of technological equipment on the floor and the selection of the optimal performance of the technological equipment considering the throughput of elevators $[5,10]$. It is also important for freight elevators to be able to carry unified, reconfigurable trolleys, which are designed for 
transportation and storage of components, finished products and manufacturing waste [13].

Based on the harmonization of the freight elevators throughput with the weight and volume performances of the cellular manufacturing on each floor [5] we will find the optimization criteria and objective functions:

$$
\begin{gathered}
\mathrm{G}_{\mathrm{W} . \mathrm{O}}=4800 \cdot \mathrm{v} \cdot \mathrm{Q}_{\mathrm{W}} \mathrm{S}\left(\mathrm{S}-\varepsilon \mathrm{S}_{\mathrm{E}}\right) / \mathrm{k}_{\mathrm{f}} \mathrm{k}_{\mathrm{s}} \mathrm{f} \mathrm{F}^{2} \varepsilon^{2} \mathrm{~S}_{\mathrm{E}}^{2} \rightarrow \max \\
\mathrm{G}_{\mathrm{V} . \mathrm{O}}=4800 \cdot \mathrm{v} \cdot \mathrm{Q}_{\mathrm{V}} \mathrm{S}\left(\mathrm{S}-\varepsilon \mathrm{S}_{\mathrm{E}}\right) / \mathrm{k}_{\mathrm{f}} \mathrm{k}_{\mathrm{s}} \mathrm{f} \mathrm{F}^{2} \varepsilon^{2} \mathrm{~S}_{\mathrm{E}}^{2} \rightarrow \max \\
\mathrm{k}_{\mathrm{f}}=(\mathrm{F}+1) / \mathrm{F} \\
\mathrm{k}_{\mathrm{S}}=1+\mathrm{v}\left[4 \lambda_{\lambda}+2\left(2 \mathrm{t}_{\mathrm{f} .1}+\mathrm{t}_{\mathrm{o}}+\mathrm{t}_{\mathrm{c}}\right)\right] / \mathrm{f}(\mathrm{F}+1)
\end{gathered}
$$$$
\text { where: }
$$

Gw.o - the optimal weight performance of the technological equipment on each floor of the multi-floor manufacturing, $\mathrm{N} / \mathrm{h}$;

Gv.o - the optimal volume performance of the technological equipment on each floor of the multi-floor manufacturing, $\mathrm{m}^{3} / \mathrm{h}$;

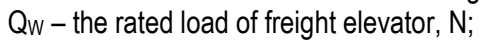

$\mathrm{Qv}$ - the nominal volume capacity of the freight elevator, $\mathrm{m}^{3}$;

$\mathrm{S}$ - total area of each floor of the multi-floor manufacturing, $\mathrm{m}^{2}$;

$S_{E}$ - the actual area occupied by the freight elevator for the multi-floor manufacturing, $\mathrm{m}^{2}$;

$\varepsilon-$ the number of the freight elevators, pcs;

$\mathrm{f}$ - the interfloor distance, $\mathrm{m}$;

$\mathrm{v}$ - the rate speed of the freight elevator, $\mathrm{m} / \mathrm{s}$;

$\mathrm{k}_{\mathrm{f}}$ - the coefficient, which depends on the number of floors of the multi-floor cellular manufacturing systems;

$k_{s}$ - the coefficient of losses of time cycle of a work of the freight elevators;

$\mathrm{t}_{\lambda}$ - the trolley loading/ unloading time, $\mathrm{s}$;

$\mathrm{t}_{\mathrm{f} .1}$ - the single floor flight time representing the time of acceleration and deceleration, s;

$\mathrm{t}_{\mathrm{O}}$ - the door opening time, $\mathrm{s}$;

$\mathrm{t}_{\mathrm{c}}$ - the door closing time, $\mathrm{s}$;

$\lambda-$ the number of the trolleys in the freight elevator, pcs.

The search for the maximum values of the objective functions can be performed by numerical methods. The complexity of the search for the optimum and several values of the variables involved in the objective functions can be significantly reduced by a preliminary assessment of freight elevators in accordance with other wellknown criteria presented in the reference literature $[6,7,8$, and 9]. The pre-selected elevator group can be used for the final analysis and making an optimal solution.

Determining the optimal values of the objective functions, we will find the total weight and volume performances of the multi-floor cellular manufacturing system:

$$
\begin{aligned}
\mathrm{G}_{\mathrm{W} . \Sigma} & =\mathrm{FG}_{\mathrm{W} . \mathrm{O}} \\
\mathrm{G}_{\mathrm{V} . \Sigma} & =\mathrm{FG}_{\mathrm{V} . \mathrm{O}}
\end{aligned}
$$

where:

$\mathrm{Gw}_{\mathrm{w} . \Sigma}$ - the total weight performance of the multi-floor cellular manufacturing system, $N / h$;

$\mathrm{G}_{\mathrm{v} . \Sigma}$ - the total volume performance of the multi-floor cellular manufacturing system, $\mathrm{m}^{3} / \mathrm{h}$.
A preliminary analysis of the obtained dependences shows that to improve the performance of the multi-floor manufacturing it is necessary to increase the capacity and volume of freight elevators. However, the analysis of technical characteristics of freight elevators available on the market showed that with the increase in load capacity and volume of freight elevators the total performance may be decreased. This is due to an increase in the area occupied by elevators, and by decreasing the speed of their movement. The search for the optimum solutions of the selection of freight elevators is facilitated if a wide range of freight elevator types are available on the market.

Current trends in miniaturizing products, the use of materials with a low specific gravity (plastics, composites, etc.) increases the significance of the volume performance criterion of the multi-floor cellular manufacturing. The selection of the priorities among the proposed criteria depends on the nature and specificity of the planned multi-floor manufacturing. However, it should be considered that the freight elevators are also used to delivery of technological equipment to the production cell of the multi-floor manufacturing. Therefore, one of the main criteria for the selection of freight elevators in the multi-floor manufacturing is also a possibility to deliver modules of the technological equipment to different floors of the building with their subsequent assembling.

The modular principle of the technological equipment design is one of the conditions for their usage in the multi-floor manufacturing. The technical criteria such as weight, overall dimensions of the modules of technological equipment can assess the possibility of their use in the multi-floor factories. Block-modular principle of the technological equipment also allows to produce rapid reengineering, recycling and utilization. Also, such criteria as the weight and overall dimensions of the technological equipment allow to assess the possibility of its layout on the selected floor of the building considering the available manufacturing areas and the bearing capacity of the building structure [5].

\section{Conclusion}

The decision criteria in the freight elevator assessment process for the multi-floor manufacturing meet the technological, economic, environmental and social requirements. We have proposed the additional criteria for the freight elevator assessment and selection for the multi-floor manufacturing that can be attributed to technical requirements. However, the proposed technical criteria also are affected by the economic, ecological and social aspects of sustainability assessment process.

The proposed criteria for the assessment and the selection of freight elevators provide the highest performance of the multi-floor cellular manufacturing. The significance of the volume performance criterion determines their carrying capacity and is a limiting factor in the selection of the bulky technological equipment for the multi-floor cellular manufacturing. Therefore, it is necessary to put the technological equipment for the multi-floor manufacturing only in the disassembled state, such as easily assembled and disassembled modules and components that can be delivered by the freight elevators to the appropriate floor for installation. In case of the removal of such equipment, its delivery to the main storage of the multi-floor manufacturing by freight elevators also needs to be implemented.

The proposed criteria for freight elevator assessment and selection can be used to support the development a general model for sustainability assessment process for the multi-floor cellular manufacturing. 


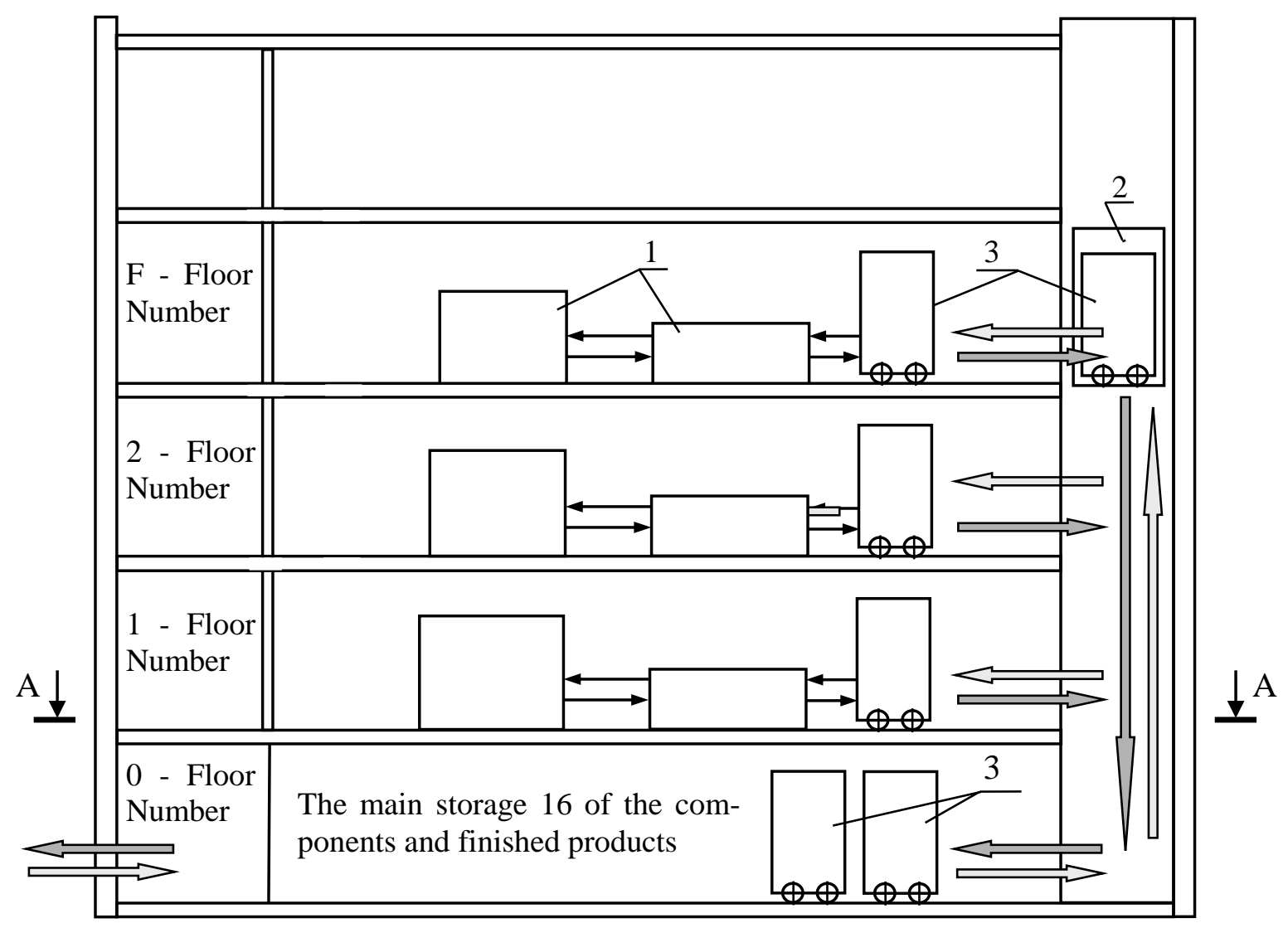

A-A

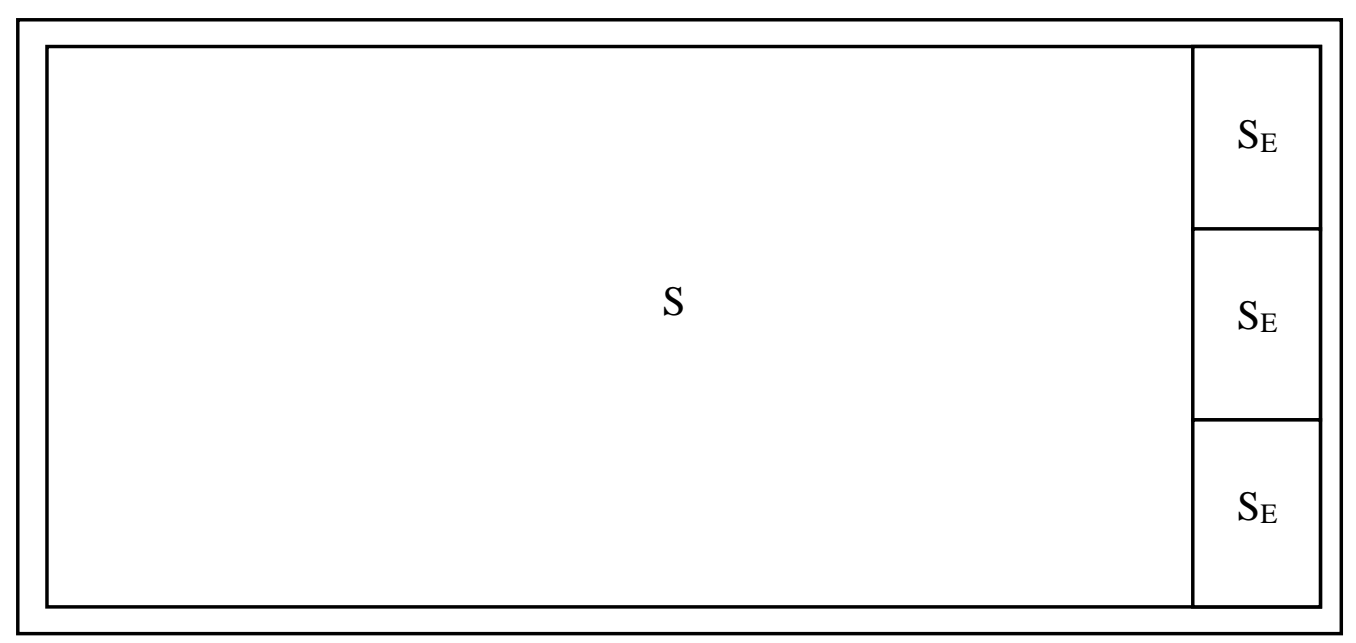

Fig. 1. Charts of the manufacturing equipment and the freight elevators layout on the floor of the multi-floor cellular manufacturing system and technological streams:

$\mathrm{S}$ - total area of each floor of the multi-floor manufacturing,

$\mathrm{S}_{\mathrm{E}}$ - the actual area occupied by a freight elevator

References:

1. Fujita Masahisa, Thisse Jacques-François, Economics of Agglomeration: Cities, Industrial Location, and Globalization, Cambridge University Press, 2002.

2. Westkämper Engelbert, Towards the Re-Industrialization of Europe. A Concept for Manufacturing for 2030, Berlin: Springer, 2014.

3. Dzhuguryan T., Jóźwiak Z., Infrastructure for multi-floor virtual enterprises system, Systemy wspomagania w inżynierii produkcji, P.A. Nowa S.A. Gliwice, 3(15), 2016, 70-78.
4. Dzhuguryan T., Design Features of Flexible Manufacturing Modules in Frame Construction, Zeszyty Naukowe Politechniki Rzeszowskiej. Mechanika, Oficyna Wydawnicza Politechniki Rzeszowskiej, z. 84[284], nr 1/2012. p. 21-25.

5. Dzhuguryan T., Jóźwiak Z, Specific approach to assessment of technologies for multi-floor manufacturing system, Autobusy: technika, eksploatacja, systemy transportowe, nr 5, 2017.

6. CIBSE Guide D: Transportation systems in building (2015), $\mathrm{http}: / / w w w . c i b s e . o r g / k n o w l e d g e / k n o w l e d g e-$ items/detail?id=a0q20000008JecyAAC 
7. Barney G., Al-Sharif L., Elevator traffic handbook: theory and practice, (2nd Ed), Routledge, London and New York, 2015.

8. Hakonen $\mathrm{H}$. and Siikonen M., Elevator traffic simulation procedure, Elevator Technology 17, IAEE, 2008.

9. Peters Richard, The application of simulation to traffic design and dispatcher testing, Proc. 3rd Symposium on Lift and Escalator Technologies, The University of Northampton, 2013.

10. Dzhuguryan T., Jóźwiak Z, Improving the logistics of the multifloor assembly manufacturing, Technologia i automatyzacja montażu, nr 2, 2016, 16-20.

11. Czajka, J., Krot, K., Kuliberda, M. Selected issues of production systems organisation and computer aided process planning: production system organisation, Reviewer: Edward Chlebus, Wrocław University of Technology; PRINTPAP, Wrocław; Łódź, 2011.

12. Dzhuguryan T., Jóźwiak Z. The transport providing of works of the multi-floor flexible production line, Autobusy: technika, eksploatacja, systemy transportowe, R17, nr 6, 2016, 1311-1314.

13. Dzhuguryan, T., Wiśnicki, B., Jóźwiak, Z. Modular Loading Units for Facilitating Multi-Floor Manufacturing and City Logistics, Zeszyty Naukowe Akademii Morskiej w Szczecinie, Wydawnictwo Naukowe Akademii Morskiej w Szczecinie, nr 54 (126), 2018, s.73-78.

\section{Specyficzne podejście do wyboru wind towarowych dla wielopiętrowej produkcji}

Zastosowanie wielopiętrowych gniazdowych systemów produkcyjnych w dużych miastach jest związane z racjonalnym wykorzystaniem obszarów miejskich i decyzji problemów komunikacyjnych. Wybór dźwigów towarowych jest ważną częścią procesu podjęcia decyzji w produkcji wielopiętrowej, co pozwala przedsiębiorstwu wybrać sprzęt z uwzględnieniem technicznych, ekonomicznych, ekologicznych, socjalnych i innych czynników. W artykule jest przedstawione specyficzne podejście do wyboru dźwigów towarowych dla wielopiętrowych gniazdowych systemów produkcyjnych. Zaproponowano model dla wyboru dźwigów towarowych z uwzględnieniem produktywności wytwarzania, przelotowości pionowego transportowego systemu i ilości pięter systemu produkcyjnego.

Słowa kluczowe: wielopiętrowa produkcja, dźwig towarowy, produktywność.

Autorzy:

prof. dr hab. inż. Tygran. Dzhuguryan - Akademia Morska w Szczecinie, e-mail: dzhuguryan@am.szczecin.pl

dr. hab. inż. Zofia Jóźwiak - Akademia Morska w Szczecinie, e-mail: z.jozwiak@am.szczecin.pl 